\title{
Standardy jakości stosowania implantów ślimakowych u niemowląt, dzieci i młodzieży
}

\section{Stanowisko Towarzystwa Otorynolaryngologów, Foniatrów i Audiologów Polskich oraz Polskiego Towarzystwa Otolaryngologów Dziecięcych}

\section{Henryk Skarżyński}

Konsultant Krajowy w Dziedzinie Otorynolaryngologii

Przewodniczący Komitetu Nauk Klinicznych Polskiej Akademii Nauk

Przewodniczący Zarządu Głównego Polskiego Towarzystwa Otolaryngologów Dziecięcych

Dyrektor Instytutu Fizjologii i Patologii Słuchu, Warszawa/Kajetany

Członek - Założyciel grupy HEARRING

\section{Grażyna Mielnik-Niedzielska}

Konsultant Krajowy w Dziedzinie Otolaryngologii Dziecięcej

Członek Komitetu Nauk Klinicznych Polskiej Akademii Nauk

Była Przewodnicząca Zarządu Głównego Polskiego Towarzystwa Otolaryngologów Dziecięcych Kierownik Kliniki Otolaryngologii Dziecięcej, Foniatrii i Audiologii Uniwersytetu

Medycznego w Lublinie

\section{Krzysztof Kochanek}

Sekretarz Komitetu Nauk Klinicznych Polskiej Akademii Nauk

Członek Zarządu Głównego Polskiego Towarzystwa Otolaryngologów Dziecięcych

Członek Komisji Rewizyjnej Polskiego Towarzystwa Inżynierii Biomedycznej

Sekretarz Naukowy Instytutu Fizjologii i Patologii Słuchu, Warszawa/Kajetany

Uniwersytet Marii Curie-Skłodowskiej, Zakład Logopedii i Językoznawstwa Stosowanego, Lublin

\section{Artur Niedzielski}

Członek Rady Towarzystwa Otorynolaryngologów, Foniatrów i Audiologów Polskich

Przewodniczący Komisji Rewizyjnej Polskiego Towarzystwa Otolaryngologów Dziecięcych

Kierownik Kliniki Otolaryngologii Dziecięcej, Centrum Medyczne Kształcenia

Podyplomowego, Warszawa

Szpital w Dziekanowie Leśnym, Oddział Laryngologii Dziecięcej

\section{Piotr H. Skarżyński}

Sekretarz Zarządu Towarzystwa Otorynolaryngologów, Foniatrów i Audiologów Polskich Wiceprzewodniczący grupy HEARRING

Zastępca Kierownika Zakładu Teleaudiologii Instytutu Fizjologii i Patologii Słuchu,

Warszawa/Kajetany

Dyrektor ds. nauki i rozwoju Instytutu Narządów Zmysłów, Kajetany

Międzynarodowe Centrum Słuchu i Mowy Medincus, Kajetany

Warszawski Uniwersytet Medyczny, II Wydział Lekarski, Zakład Niewydolności Serca i Rehabilitacji Kardiologicznej

\section{Artur Lorens}

Członek Towarzystwa Otorynolaryngologów, Foniatrów i Audiologów Polskich

i Polskiego Towarzystwa Otolaryngologów Dziecięcych

Kierownik Zakładu Implantów i Percepcji Słuchowej Instytutu Fizjologii i Patologii

Słuchu, Warszawa/Kajetany

Członek grupy HEARRING 


\section{Spis treści}

1. Wprowadzenie

2. Skład zespołu

3. Pomieszczenia (tam, gdzie ma to zastosowanie)

4. Wyposażenie kliniczne

5. Kryteria kwalifikacji pacjentów do diagnostyki i wszczepienia implantu ślimakowego

6. Proces diagnostyczny i decyzyjny

7. Przedoperacyjne informacje dla rodziców/opiekunów i świadoma zgoda

8. Zabieg chirurgiczny i hospitalizacja

9. Uruchomienie i dopasowanie procesora mowy po operacji

10. (Re)habilitacja i ocena po operacji

11. Badania kontrolne i długookresowe utrzymanie urządzenia

12. Awaria urządzenia

13. Zarządzanie programem implantów ślimakowych

14. Współpraca zespołu implantów ślimakowych $\mathrm{z}$ innymi zespołami i instytucjami

15. Przeniesienie opieki nad pacjentem (w kraju)

16. Opinie i skargi

„Standardy jakości stosowania implantów ślimakowych u niemowląt, dzieci i młodzieży" zostały opracowane przez zespół Konsultanta Krajowego w Dziedzinie Otorynolaryngologii oraz przez Towarzystwo Otorynolaryngologów, Foniatrów i Audiologów Polskich i Polskie Towarzystwo Otolaryngologów Dziecięcych, na podstawie standardów wydanych przez grupę HEARRING. HEARRING jest naukową siecią współpracy eksperckiej w dziedzinie implantów słuchowych. Jest to stowarzyszenie wiodących międzynarodowych ośrodków oferujących wszechstronne rozwiązania z zakresu implantów słuchowych stosowanych w leczeniu wad słuchu.

Zestaw standardów jakości został opracowany w celu zapewnienia wysokiego poziomu opieki zdrowotnej i skuteczności stosowania implantów ślimakowych oraz w celu zapewnienia każdemu dziecku najlepszego leczenia z zastosowaniem implantu ślimakowego optymalnie dobranego do jego wady słuchu. Standardy te stanowią realistyczne minimum i powinny być stosowane łącznie z aktualnymi Zasadami Dobrej Praktyki Klinicznej.

\section{Wprowadzenie}

Wszczepienie implantu ślimakowego jest terapią multidyscyplinarną, której kluczowym elementem jest zabieg chirurgiczny polegający na wprowadzeniu wiązki elektrod do ślimaka w celu zapewnienia bezpośredniej, elektrycznej stymulacji nerwu słuchowego. Liczne badania naukowe wykazały, że jest to procedura bezpieczna i skuteczna.

Wszczepienie implantu ślimakowego jest rekomendowane dla niemowląt, dzieci i młodzieży z głuchotą i częściową głuchotą typu odbiorczego, które nie uzyskują zadowalających korzyści z zastosowania aparatów słuchowych. Implanty ślimakowe omijają niedziałającą część receptorową układu słuchowego w celu dostarczenia sygnałów elektrycznych bezpośrednio do nerwu słuchowego.

Powszechne badania przesiewowe słuchu noworodków umożliwiają wczesne wykrycie wrodzonego niedosłuchu, a następnie podjęcie wczesnej interwencji. Dzieci, które zostaną zaimplantowane odpowiednio wcześnie, mają dostęp do informacji uzyskiwanych drogą słuchową i dzięki temu są mniej podatne na zmiany funkcjonalne powodowane przez deprywację słuchową.

System implantu ślimakowego składa się z dwóch części: wewnętrznej i zewnętrznej.

\subsection{Część wewnętrzna}

W skład części wewnętrznej wchodzi element elektroniczny w obudowie (kapsule), wiązka elektrod, antena odbiorcza oraz magnes do zamocowania cewki na głowie za uchem.

\subsection{Część zewnętrzna}

Procesor mowy składa się z układu sterującego, pojemnika na baterie/akumulatorki i cewki przesyłającej informacje przez skórę do części wewnętrznej.

\section{Skład zespołu}

2.1 Skład zespołu pediatrycznego implantów ślimakowych

Zespół pediatryczny implantów ślimakowych może funkcjonować jako niezależny zespół lub wchodzić w skład większej jednostki w ośrodku implantów ślimakowych. Jest to zespół multidyscyplinarny, w skład którego wchodzą następujący specjaliści:

a. Chirurdzy otolaryngolodzy

Chirurg ponosi odpowiedzialność za operację wszczepienia implantu ślimakowego.

W skład zespołu musi wchodzić co najmniej dwóch chirurgów z doświadczeniem w zakresie otologii i chirurgii implantów ślimakowych. Zalecane jest, aby wykonywali oni co najmniej 20 operacji wszczepienia implantu ślimakowego rocznie.

Chirurdzy przyjmowani do zespołu powinni posiadać wyszkolenie specjalistyczne na poziomie zaawansowanym w zakresie otologii i chirurgii implantów ślimakowych, zdobyte w odpowiednich ośrodkach specjalistycznych w swoim kraju lub za granicą. Powinno ono obejmować udział w kursie praktycznym dla chirurgów z zakresu implantów ślimakowych, obejmującym ćwiczenia na preparatach kości skroniowych. Nowo przyjęty chirurg początkowo powinien pracować pod opieką doświadczonego członka (członków) zespołu, przy czym przynajmniej przez pierwsze sześć miesięcy powinien wykonywać odpowiednią liczbę operacji wszczepienia implantu ślimakowego pod nadzorem doświadczonego chirurga $\mathrm{z}$ zespołu.

\section{b. Anestezjolog dziecięcy}

W skład zespołu chirurgicznego powinien wchodzić anestezjolog dziecięcy posiadający umiejętności i doświadczenie $\mathrm{w}$ zakresie postępowania $\mathrm{z}$ małymi dziećmi. Jest to wyjątkowo ważne, gdyż znieczulenie ogólne może być 
źródłem szczególnego ryzyka dla dzieci o niewielkiej masie ciała. Ryzyko to jest znacząco wyższe w przypadku dzieci poniżej 12 miesiąca życia. Można je zmniejszyć, jeżeli znieczulenie wykonywane jest przez doświadczonego anestezjologa dziecięcego.

\section{c. Zespół podstawowy}

W skład zespołu podstawowego powinny wchodzić osoby posiadające odpowiednie wyszkolenie i doświadczenie w zakresie doboru aparatów słuchowych dla pacjentów pediatrycznych z niedosłuchem znacznym do głębokiego, bardzo dobrze znające zagadnienia z dziedziny implantów ślimakowych, ich programowania oraz rehabilitacji słuchu i mowy. W skład zespołu wchodzą:
1. audiolodzy,
2. psycholodzy,
3. surdologopedzi,
4. inżynierowie kliniczni,
5. surdopedagodzy.

Osoby te powinny posiadać wykształcenie wyższe z dyplomem magistra lub równoważnym. Ponadto muszą mieć co najmniej dwuletni staż pracy w zawodzie.

Dodatkowo osoby te powinny, w miarę możliwości, posiadać rozległe doświadczenie kliniczne w zakresie implantów ślimakowych, połączone ze znajomością i zrozumieniem zagadnień związanych z multidyscyplinarnym charakterem opieki nad pacjentem $\mathrm{z}$ implantem ślimakowym. Ich zadania powinny także obejmować szersze obowiązki naukowo-badawcze.

\section{d. Koordynator/kierownik zespołu podstawowego}

Koordynator/kierownik zespołu kieruje działalnością kliniczną zespołu i odpowiada za obsługę pacjentów.

Osoba na tym stanowisku musi mieć odpowiednie doświadczenie kliniczne i tytuł doktora, posiadać odpowiednią wiedzę (obejmującą znajomość zagadnień multidyscyplinarnych) i kompetencje, uzupełnione o szkolenia specjalistyczne i doświadczenie (najlepiej co najmniej 10-letnie) w dziedzinie implantów ślimakowych.

\section{e. Administrator/sekretarz}

Administrator powinien posiadać odpowiednie kwalifikacje do prowadzenia sekretariatu, dobre zdolności organizacyjne i komunikacyjne oraz wysoki poziom umiejętności obsługi komputera. Administrator ściśle współpracuje z koordynatorem/kierownikiem zespołu.

\section{f. Pracownik prowadzący}

Dla każdej rodziny musi zostać wyznaczony pracownik prowadzący, który będzie pomagał i pośredniczył w kontaktach $\mathrm{z}$ ośrodkiem implantów ślimakowych. Może być nim jeden $\mathrm{z}$ wyżej wymienionych członków zespołu podstawowego.

g. Członkowie zespołu powinni należeć do właściwych krajowych i/lub międzynarodowych stowarzyszeń zawodowych specjalistów zajmujących się implantami ślimakowymi.

h. Członkowie zespołu powinni regularnie brać udział w szkoleniach na temat nowych rozwiązań naukowo-technicznych w dziedzinie implantów ślimakowych. Zalecane jest także, by uczestniczyli oni w odpowiednich kursach, konferencjach i spotkaniach na poziomie krajowym i międzynarodowym. Wszyscy członkowie zespołu powinni mieć możliwość regularnego uczestniczenia w konferencjach krajowych, jak również posiadać plan kształcenia ustawicznego w celu dalszego rozwoju zawodowego.

i. Wszyscy członkowie zespołu powinni zostać przeszkoleni w zakresie podstawowych informacji o kulturze Głuchych $^{1}$ i praktycznych zagadnień związanych z komunikacją $\mathrm{z}$ osobami niesłyszącymi.

j. Nowo przyjęci członkowie zespołu, z mniejszym doświadczeniem, muszą przejść odpowiedni program szkolenia i pracy pod nadzorem odpowiednich doświadczonych członków zespołu.

\subsection{Dodatkowe wsparcie}

Zespół podstawowy powinien posiadać odpowiednie umiejętności i doświadczenie, zgodnie z wymaganiami opisanymi w pkt 2.1.c. Jeżeli w skład zespołu podstawowego nie wchodzą specjaliści w zakresie:

a. leczenia szumów usznych,

b. leczenia zaburzeń równowagi,

c. radiologii,

d. fizyki medycznej,

e. poradnictwa genetycznego,

f. psychologii,

g. psychiatrii,

h. pediatrii,

i. pedagogiki,

j. tłumaczenia $\mathrm{z}$ języka migowego,

k. pomocy społecznej dla osób niesłyszących i niedosłyszących,

1. pomocy prawnej dla osób niesłyszących i niedosłyszących,

należy zapewnić pacjentom dostęp do tych specjalistów, gdyby zaistniała taka potrzeba. Specjaliści ci powinni posiadać odpowiednie wyszkolenie i doświadczenie.

Rodzice/opiekunowie odgrywają kluczową rolę w procesie terapii dziecka $\mathrm{z}$ wadą słuchu. Obowiązkiem członków zespołu implantów ślimakowych jest partnerska współpraca $\mathrm{z}$ rodzicami/opiekunami w celu zapewnienia im potrzebnego wsparcia, dzięki któremu będą mogli oni prawidłowo stymulować rozwój dziecka.

\section{Pomieszczenia}

3.1 Wszystkie pomieszczenia, z których korzystają pacjenci, muszą być przystosowane do potrzeb osób niesłyszących

\footnotetext{
${ }^{1}$ Pisownia dużą literą G - zgodna z tradycją amerykańską - odnosi się do modelu głuchoty, w którym ludzie głusi uznawani są za mniejszość językową i kulturową.
} 
i niedosłyszących. Oznacza to m.in. stosowanie powiadomień wizualnych (np. wezwanie do gabinetu), alarmów wizualnych (np. alarm pożarowy) i odpowiednich urządzeń wspomagających słyszenie.

3.2 Pomieszczenia kliniczne powinny być odpowiedniej wielkości, by wygodnie pomieścić dziecko i członków rodziny, pracowników klinicznych i obserwatorów lub tłumaczy języka migowego oraz potrzebne wyposażenie.

3.3 Pomieszczenia przeznaczone dla dzieci powinny być łatwo dostępne, bezpieczne i odpowiednio przystosowane do potrzeb rodziny $\mathrm{z}$ dzieckiem. Pomieszczenia te powinny być położone $\mathrm{w}$ obrębie ośrodka implantów ślimakowych lub oddziału otorynolaryngologii/audiologii dziecięcej w szpitalu.

3.4 Należy zapewnić odpowiedni pokój do pracy zespołowej, takiej jak zajęcia grupowe użytkowników implantów ślimakowych i spotkania/szkolenia zespołu.

3.5 Należy zapewnić odpowiednią poczekalnię w pobliżu pokojów konsultacyjnych. Poczekalnia musi być wystarczająco duża i wyposażona w odpowiednią liczbę wygodnych krzeseł, aby pomieścić wszystkich pacjentów, którzy mogą równocześnie oczekiwać na konsultację.

3.6 Pokoje konsultacyjne powinny być odpowiednio oddzielone od poczekalni, aby dobiegający $\mathrm{z}$ niej hałas nie przeszkadzał $\mathrm{w}$ postępowaniu leczniczo-terapeutycznym i możliwe było zachowanie prywatności. Pokoje konsultacyjne powinny być dobrze oświetlone, w sposób odpowiadający potrzebom dzieci z upośledzeniem widzenia.

3.7 Wszystkie pomieszczenia muszą spełniać wymogi zawarte w odpowiednich przepisach i wytycznych odnośnie zdrowia i bezpieczeństwa oraz muszą być dostosowane do celów, którym służą.

\section{Wyposażenie kliniczne}

4.1 Ośrodek musi posiadać wyposażenie kliniczne do wykonywania następujących badań:

a. audiometria tonalna dostosowana do wieku dziecka,

b. badania percepcji mowy,

- w ciszy,

- w szumie,

c. audiometria wolnego pola, ze specjalnym wyposażeniem testowym dla niemowląt i małych dzieci,

d. dopasowanie aparatów słuchowych, w tym pomiary in situ,

e. tympanometria,

f. badanie otoemisji akustycznych,

g. badanie słuchowych potencjałów wywołanych,

h. badania funkcji równowagi,

i. badania obrazowe,

j. badania lokalizacji dźwięku.

4.2 Wyposażenie do badań audiologicznych
Sprzęt audiologiczny musi spełniać normy krajowe. Powinien być kalibrowany zgodnie $\mathrm{z}$ wymaganiami, $\mathrm{z}$ zastosowaniem zalecanych metod, oraz powinien być codziennie testowany. Wszystkie badania powinny być wykonywane zgodnie $\mathrm{z}$ zalecanymi zasadami postępowania i procedurami.

\section{Kryteria kwalifikacji pacjentów do diagnostyki i wszczepienia implantu ślimakowego}

5.1 Wytyczne odnośnie kierowania pacjentów na diagnostykę w kierunku wszczepienia implantu ślimakowego i kryteria kwalifikacji do wszczepienia implantu powinny być dostępne na życzenie w formie pisemnej.

5.2 Kryteria kwalifikacji dzieci do wszczepienia implantu ślimakowego (w szczególności niemowląt poniżej 12 miesiąca życia) są w niniejszym dokumencie zdefiniowane bardzo szeroko, gdyż obecnie zmieniają się one dynamicznie. Należy jednak stwierdzić, że:

a. Dziecko kwalifikowane do wszczepienia implantu ślimakowego może mieć obustronny niedosłuch typu odbiorczego od znacznego do głębokiego stopnia lub częściową głuchotę.

b. Rodzice/opiekunowie dziecka powinni mieć realistyczne oczekiwania w odniesieniu do procedury wszczepienia implantu ślimakowego i możliwych do osiągnięcia efektów.

c. Rodzice/opiekunowie dziecka muszą mieć zapewniony odpowiedni dostęp do opieki i usług po wszczepieniu implantu ślimakowego, takich jak (re)habilitacja i edukacja, aby dziecko mogło uzyskać jak najlepsze wyniki.

5.3 Powinna być przeprowadzana regularna ewaluacja kryteriów kwalifikacji pacjentów do wszczepienia implantu ślimakowego stosowanych w danym ośrodku, aby zapewnić ich zgodność $\mathrm{z}$ aktualnym stanem wiedzy.

\section{Proces diagnostyczny i decyzyjny}

Proces diagnostyczny powinien zostać przeprowadzony możliwie najbardziej sprawnie i szybko.

6.1 Jeżeli nie ma przeciwwskazań klinicznych, wszystkie dzieci powinny przejść pełen proces diagnostyczny w kierunku wszczepienia implantu ślimakowego. Jego celem jest ocena funkcji słuchowych dziecka i ustalenie, czy mogą one ulec znaczącej poprawie dzięki wszczepieniu implantu ślimakowego.

6.2 Konieczne jest wdrożenie spójnego zarządzania procesem oceny pacjenta przed wszczepieniem implantu ślimakowego prowadzonego przez wyznaczonego koordynatora. Należy stosować przyjęte kryteria kwalifikacji do implantu.

6.3 W przypadku każdego dziecka procedura diagnostyczna musi być prowadzona zgodnie z pisemną listą kontrolną i zarejestrowana w jego karcie szpitalnej.

6.4 Czas oczekiwania na badania diagnostyczne i podjęcie leczenia powinien być możliwie jak najkrótszy i zgodny $\mathrm{z}$ odpowiednimi wytycznymi. Po zakończeniu procesu diagnostycznego rodzice/opiekunowie powinni otrzymać 
informację o zakwalifikowaniu bądź niezakwalifikowaniu dziecka do wszczepienia implantu ślimakowego.

6.5 W klinicznie uzasadnionych przypadkach musi być możliwe skierowanie pacjenta na szybką ścieżkę diagnostyczną.

6.6 Diagnostyka przedoperacyjna powinna obejmować:

6.6.1 Badania lekarskie

a. Wszystkie dzieci skierowane do ośrodka implantów ślimakowych muszą zostać zbadane przez otolaryngologa/audiologa należącego do zespołu implantów ślimakowych.

b. Skierowanie dziecka na badanie za pomocą rezonansu magnetycznego, na tomografię komputerową lub prześwietlenie rtg leży w zakresie odpowiedzialności lekarza prowadzącego proces diagnostyczny.

c. Skierowanie dziecka - w razie potrzeby - na badanie równowagi/funkcji narządu przedsionkowego.

d. Omówienie wszystkich przed-i pooperacyjnych zagrożeń związanych z zabiegiem.

e. Wskazanie na potrzebę wykonania szczepienia w celu zminimalizowania ryzyka pneumokokowego zapalenia opon mózgowo-rdzeniowych.

f. Skierowanie dziecka - w razie potrzeby - na konsultację genetyczną.

g. Uzyskanie w pełni świadomej zgody rodziców/ opiekunów pacjenta na przeprowadzenie zabiegu.

h. Potwierdzenie, że dziecko zostało przebadane okulistycznie, gdyż optymalne widzenie ma zasadnicze znaczenie dla dziecka $\mathrm{z}$ niedosłuchem.

6.6.2 Badania audiologiczne

6.6.2.1 Każde dziecko musi przejść pełną diagnostykę audiologiczną zgodną z protokołem.

6.6.2.2. Badanie audiologiczne musi zawierać:

(1) Badanie otoskopowe uszu.

(2) Oznaczenie progów słyszenia w obojgu uszach za pomocą audiometrii tonalnej lub innej uznanej metody odpowiedniej do wieku rozwojowego i kondycji dziecka.

(3) Obiektywną ocenę progu słyszenia w obojgu uszach, która jest jedną z podstawowych metod oceny kandydata do implantu ślimakowego. W tym celu należy wykonać następujące badania:

a. otoemisje akustyczne (OAA),

b. słuchowe potencjały wywołane pnia mózgu (ABR) lub/i słuchowe potencjały wywołane stanu ustalonego (ASSR).

(4) Ocenę funkcjonowania prawego i lewego ucha środkowego za pomocą technik tympanometrycznych.
(5) Dostosowane do wieku pacjenta badanie dyskryminacji dźwięków, w tym dźwięków mowy w ciszy i w szumie.

(6) Badanie kwestionariuszowe dla rodziców dotyczące zachowań dziecka związanych ze słyszeniem.

(7) Badanie i ocenę pod kątem aparatów słuchowych, najlepiej potwierdzone metodami niebehawioralnymi.

\subsubsection{Ocena korzyści z aparatów słuchowych}

Przed wszczepieniem implantu ślimakowego każde dziecko powinno zostać obustronnie zaopatrzone w aparaty słuchowe zapewniające mu słyszenie możliwie najszerszego zakresu dźwięków. W trakcie procesu diagnostycznego ich dopasowanie należy zweryfikować i w razie potrzeby poprawić ustawienia lub dopasować dziecku nowe aparaty słuchowe. Należy zweryfikować, czy wzmocnienie jest właściwe, stosując w zależności od wieku i indywidualnych możliwości dziecka:

a. pomiary in situ,

b. audiometrię $\mathrm{w}$ polu swobodnym $\mathrm{w}$ aparatach słuchowych,

c. badania percepcji dźwięków otoczenia i/lub mowy z wykorzystaniem wystandaryzowanego nagranego materiału,

d. pomiary elektroakustyczne charakterystyki aparatów słuchowych zgodnie z obowiązującymi standardami.

6.6.4 Dzieci, którym dopasowano nowe aparaty słuchowe lub u których zostały zmienione ustawienia aparatów słuchowych, mogą potrzebować adaptacji do aparatów i/lub odpowiednio zaplanowanej (re)habilitacji słuchowej. U niektórych dzieci okres adaptacji może trwać do kilku miesięcy.

\subsubsection{Ocena sposobów komunikacji}

Konieczne może być przeprowadzenie pełnej oceny stosowanych przez dziecko sposobów komunikacji i funkcjonowania społecznego. Ocena ta może mieć formę obserwacji, opisu subiektywnego lub oceny z zastosowaniem formalnej procedury testowej. Musi ona uwzględniać wiek dziecka i stan jego słuchu, jego zdolności w zakresie odbioru i ekspresji mowy, jak również indywidualne uwarunkowania.

Ocena może dotyczyć następujących obszarów:

a. możliwości słuchowe w zakresie odbioru mowy (u bardzo małych dzieci zachowania przedsłowne),

b. możliwości ekspresji (głużenie, gaworzenie, okres wstępu do wyrazu, słowa, jakość głosu oraz zrozumiałość mowy),

c. należy zebrać szczegółowe informacje na temat tego, w jakim otoczeniu dziecko zwykle się komunikuje i kiedy sprawia mu to najwięcej trudności.

\subsection{Wsparcie psychologiczne rodziny}

Niektóre rodziny mogą potrzebować dodatkowego wsparcia lub oceny psychologicznej. Skierowanie do psychologa 
lub psychiatry należy wydać w razie zaobserwowania u rodziców/opiekunów wysokiego poziomu stresu rodzicielskiego, nieumiejętności radzenia sobie z diagnozą głuchoty dziecka, braku motywacji do uczestniczenia w procesie leczniczo-rehabilitacyjnym lub istnienia nierealistycznych oczekiwań odnośnie efektów wszczepienia implantu ślimakowego. Skierowanie powinno zostać wydane w sytuacji, gdy wskazanych problemów nie można rozwiązać w ramach poradnictwa psychologicznego oferowanego przez zespół podstawowy.

\subsection{Wsparcie i edukacja rodziny}

Rodzice/opiekunowie dziecka odgrywają kluczową rolę w procesie leczniczo-rehabilitacyjnym. Bardzo ważne jest zatem upewnienie się, że rozumieją oni cały ten proces i są odpowiednio zmotywowani do uczestniczenia $\mathrm{w}$ nim. Istotne znaczenie, zapewniające długoterminowe powodzenie leczenia, ma także wsparcie zapewniane dziecku przez osoby i instytucje zewnętrzne, takie jak szkoła.

\subsection{Organizacje wspierające}

Dzieci i rodzice/opiekunowie powinni otrzymać informacje o organizacjach wspierających użytkowników implantów ślimakowych, organizacjach charytatywnych i stowarzyszeniach samopomocowych oraz o urządzeniach i usługach dla osób z wadami słuchu.

\subsection{Wynik końcowy}

Na zakończenie postępowania diagnostycznego powinno zostać zaplanowane spotkanie $\mathrm{z}$ rodziną, na którym zostaną omówione wszystkie aspekty dotyczące wszczepienia implantu ślimakowego. Jeżeli wyniki badań diagnostycznych wskazują, że dla tego dziecka implant ślimakowy nie jest zalecany, należy wytłumaczyć rodzinie powody decyzji o dyskwalifikacji. Podczas rozmowy należy przedstawić zalecane strategie dalszego leczenia i w razie potrzeby wystawić pacjentowi skierowanie na inne urządzenia $\mathrm{i} / \mathrm{lub}$ świadczenia medyczne oraz omówić możliwości ponownego skierowania na diagnostykę w kierunku wszczepienia implantu ślimakowego w przyszłości.

6.11 Kandydaci do implantacji jednostronnej lub obustronnej

Obustronne wszczepienie implantów ślimakowych uznaje się obecnie za najnowocześniejszą strategię postępowania, stwarzającą pacjentowi największe szanse na uzyskanie maksymalnego poziomu rozumienia mowy. Obustronne wszczepienie implantów należy rozważyć w każdym uzasadnionym przypadku, natomiast wszczepienie jednego implantu - u pacjentów z jednostronną głuchotą lub asymetrycznym niedosłuchem.

\section{Przedoperacyjne informacje dla rodziców/ opiekunów i świadoma zgoda}

7.1 Podstawowe informacje i porady powinny zostać udzielone zgodnie z zapisaną listą kontrolną, odpowiednią notatkę należy umieścić w karcie szpitalnej dziecka.
7.2 Jeżeli tylko jest to możliwe, informacje powinny być udzielane w języku lub w sposób zgodny z preferowanym sposobem komunikacji przyjętym $\mathrm{w}$ danej rodzinie.

7.3 W razie potrzeby powinni być dostępni tłumacze języka migowego.

7.4 Zespoły powinny na bieżąco uaktualniać informacje, które udzielane są pacjentom; powinny mieć spisaną procedurę, określającą, jakich informacji należy udzielać i w jakim czasie.

7.5 Informacja udzielona ustnie powinna być w razie potrzeby potwierdzona pisemnym podsumowaniem.

7.6 Rodzice/opiekunowie dziecka muszą otrzymać pełne, obiektywne i aktualne informacje, aby mogli dokonać świadomego wyboru dla swojego dziecka i wyrazić, gdy będzie to konieczne, świadomą zgodę na zabieg.

7.7 Przez cały czas trwania procesu diagnostycznego wszystkie strony powinny być świadome, jakie są korzyści i ograniczenia związane $\mathrm{z}$ terapią $\mathrm{z}$ zastosowaniem implantu ślimakowego.

7.8 Zaleca się, by rodziny pacjentów diagnozowanych $\mathrm{w}$ kierunku wszczepienia implantu ślimakowego spotykały się z innymi dziećmi i rodzinami posiadającymi doświadczenie $\mathrm{w}$ korzystaniu $\mathrm{z}$ tych urządzeń. Dobre efekty może przynieść dobranie kandydatów i użytkowników pod kątem wieku, czasu trwania głuchoty i typu implantu ślimakowego.

7.9 W celu przygotowania dziecka i jego rodziców/opiekunów do pobytu w szpitalu należy zaproponować odwiedzenie przed operacją pediatrycznego oddziału chirurgicznego, dając możliwość spotkania się z zespołem pielęgniarskim.

7.10 Wybór urządzenia powinien stanowić część procesu diagnostycznego i kończącego go procesu decyzyjnego.

Aktualnie systemy implantów ślimakowych są dostarczane przez różnych producentów. Należy udostępnić pacjentom informacje na temat specyfikacji technicznych różnych urządzeń.

Rodzice/opiekunowie dziecka powinni otrzymać obszerne informacje na temat aktualnie dostępnych urządzeń, ich zalet i wad. Należy im wyjaśnić, dlaczego oferowany jest im konkretny system implantu lub wybór implantów. Informacje o zaoferowanym urządzeniu lub urządzeniach powinny być dostępne także w formie pisemnej.

Ośrodki muszą oferować i wszczepiać jedynie te implanty ślimakowe, które uzyskały zgodne z prawem certyfikaty dopuszczenia do stosowania.

7.11 Implant ślimakowy proponowany dziecku musi:

a. Posiadać udokumentowaną historię potwierdzającą jego bezpieczeństwo i niezawodność. 
b. Posiadać wszystkie wymagane certyfikaty i zgody na dopuszczenie do stosowania.

c. Mieć zapewnione przez producenta najwyższej jakości wsparcie kliniczne i techniczne.

d. Spełniać właściwe wymagania krajowe dotyczące zakupu tego rodzaju urządzeń.

7.12 Informacji o wszystkich znanych czynnikach ryzyka związanych z wszczepieniem implantu ślimakowego należy udzielić w sposób jasny i odpowiedni dla pacjenta. Informacja ta powinna być zawsze dostępna w formie pisemnej. Przed wszczepieniem implantu rodzice/ opiekunowie muszą podpisać formalną zgodę na zabieg operacyjny.

\section{Zabieg chirurgiczny i hospitalizacja}

8.1 Chirurg wszczepiający implant ślimakowy odpowiada za całokształt opieki medycznej nad dzieckiem w trakcie zabiegu i po wszczepieniu implantu.

8.2 Znieczulenie powinno zostać wykonane przez odpowiednio wykwalifikowany i doświadczony personel pediatryczny.

8.3 Chirurg powinien dołożyć wszelkich starań, aby zachować struktury wewnętrzne ślimaka i istniejące u dziecka resztki słuchowe. Stosowane przez niego techniki chirurgiczne muszą być zgodne $\mathrm{z}$ najnowszym stanem wiedzy i techniki medycznej w tej dziedzinie.

8.4 Podczas zabiegu chirurg powinien dołożyć wszelkich starań, aby uchronić nerw twarzowy przed uszkodzeniem.

8.5 Umiejscowienie kapsuły implantu może wymagać szczególnej rozwagi w przypadku bardzo drobnych niemowląt. Należy uwzględnić indywidualne właściwości ich czaszki i stopień rozwoju istotnych elementów anatomicznych.

8.6 Informacja odnośnie wyniku zabiegu chirurgicznego musi zostać udokumentowana i udostępniona zespołowi implantów ślimakowych i zespołowi (re)habilitacyjnemu.

8.7 Należy rozważyć przeprowadzenie śródoperacyjnej lub pooperacyjnej diagnostyki obrazowej w celu oceny położenia kapsuły i/lub elektrody implantu.

8.8 Chirurg wszczepiający implant ślimakowy będzie na bieżąco monitorował postępy dziecka w okresie pooperacyjnym i będzie odpowiedzialny za rozwiązywanie wszelkich problemów chirurgicznych lub medycznych, jakie mogą wystąpić w związku z implantem.

8.9 Przed wypisaniem dziecka ze szpitala rodzice/opiekunowie powinni:

a. Otrzymać pisemną informację na temat właściwej pielęgnacji rany/ucha i leczenia bólu.

b. Otrzymać pisemne wskazówki, co należy robić w razie wystąpienia problemów medycznych lub chirurgicznych.

c. Znać ustalenia odnośnie wizyt kontrolnych i dalszego postępowania. d. Otrzymać wskazówki odnośnie bezpieczeństwa i higieny korzystania $z$ implantu ślimakowego oraz pisemne wytyczne producenta na temat bezpieczeństwa.

\section{Uruchomienie i dopasowanie procesora mowy po operacji}

9.1 Procesor mowy powinien zostać uruchomiony i zaprogramowany, gdy tylko rana pooperacyjna będzie wystarczająco zagojona.

9.2 Procesor mowy powinien być uruchamiany i programowany wyłącznie przez doświadczonego pracownika klinicznego (patrz 2.1.c), w pełni przeszkolonego w zakresie odpowiednich zasad i procedur postępowania.

9.3 Przed pierwszym podłączeniem procesora mowy (aktywacją systemu implantu) odpowiedni członek zespołu musi:

a. Sprawdzić zewnętrzne części systemu implantu ślimakowego.

b. Wyjaśnić przebieg procesu dopasowania implantu.

9.4 Każdy implant ślimakowy powinien zostać dopasowany i zaprogramowany zgodnie z zalecanymi przez producenta procedurami programowania i w taki sposób, by zmaksymalizować korzyści słuchowe dziecka. Każdemu pacjentowi należy zaoferować odpowiednią liczbę sesji programowania procesora stosownie do jego potrzeb.

9.5 Zalecane jest przeprowadzenie pomiarów obiektywnych, takich jak telemetria impedancyjna, elektrycznie wywołany potencjał czynnościowy (eCAP) lub elektrycznie wywołany odruch z mięśnia strzemiączkowego (eSRT). Wyniki tych pomiarów mogą posłużyć do ustalenia poziomów stymulacji.

9.6 Rodzicom/opiekunom należy udzielić dokładnych wyjaśnień na temat używania procesora mowy. Należy ich zachęcać do kontaktu ze specjalistami z zespołu implantów ślimakowych w razie jakichkolwiek pytań lub wątpliwości.

9.7 Rodzicom/opiekunom należy wydać drukowane materiały na temat obsługi i eksploatacji procesora mowy.

9.8 Dziecku trzeba zapewnić swobodny dostęp do ośrodka implantów ślimakowych (lub wyznaczonego lokalnego ośrodka współpracującego) w celu kontroli systemu implantu lub przeprogramowania procesora mowy.

\section{0 (Re)habilitacja i ocena po operacji}

10.1 Po operacji wszczepienia implantu ślimakowego dziecko musi zostać zbadane przez otolaryngologa i mieć możliwość skorzystania $\mathrm{w}$ razie potrzeby $\mathrm{z}$ dodatkowych konsultacji.

Dziecko powinno mieć zapewnioną możliwość korzystania z opieki długoterminowej (corocznej konsultacji medycznej i kontroli działania implantu i procesora mowy). 
$10.2(\operatorname{Re})$ habilitacja pooperacyjna powinna się rozpocząć po aktywacji systemu implantu, zgodnie $\mathrm{z}$ indywidualnymi potrzebami pacjenta.

10.3 Program (re)habilitacji może obejmować zajęcia ukierunkowane na:

a. wykrywanie dźwięków i ich lokalizację,

b. słuchowe różnicowanie i rozpoznawanie dźwięków,

c. jakość głosu,

d. zrozumiałość mowy,

e. rozwój języka, rozumienia i wypowiadania się,

f. funkcjonowanie społeczne.

10.4 Program (re)habilitacji powinien być indywidualnie dopasowany do potrzeb każdego pacjenta.

10.5 Oferowana liczba sesji (re)habilitacyjnych powinna być wystarczająca do uzyskania optymalnych korzyści z implantu. Rodzice/opiekunowie i dzieci muszą mieć zapewniony swobodny dostęp do ośrodka implantów ślimakowych (lub wyznaczonego lokalnego ośrodka współpracującego) w celu skorzystania w razie potrzeby $\mathrm{z}$ (re)habilitacji i poradnictwa.

10.6 W regularnych odstępach czasu należy wykonywać odpowiednie pomiary, by monitorować zmiany w zakresie wyników audiologicznych, percepcji mowy, rozwoju mowy i języka oraz osiągnięć szkolnych dziecka. Należy stosować pomiary wystandaryzowane, by umożliwić porównywanie wyników.

10.7 Po upływie pierwszego roku od wszczepienia implantu dziecku należy zaoferować coroczne audiologiczne badania kontrolne. Mogą one mieć formę wizyty kontrolnej wyznaczonej przez ośrodek implantów ślimakowych lub zainicjowanej przez pacjenta. Ponadto rodzice/opiekunowie powinni mieć możliwość umówienia się $\mathrm{w}$ razie potrzeby na dodatkowe konsultacje dla dziecka.

10.8 Należy rozważyć wysyłanie pisemnych sprawozdań o postępach dziecka specjalistom zaangażowanym w opiekę nad dzieckiem w miejscu jego zamieszkania.

\section{Badania kontrolne i długookresowe utrzymanie urządzenia}

11.1 Dziecko i rodzice/opiekunowie muszą mieć zapewniony swobodny dostęp do ośrodka implantów ślimakowych (lub wyznaczonego lokalnego ośrodka współpracującego) w celu ustawienia procesora mowy, rehabilitacji lub konsultacji chirurgicznej.

11.2 Odpowiednie akcesoria, części lub elementy zamienne procesora mowy muszą być dostępne w razie potrzeby w punktach serwisowych autoryzowanych przez producentów urządzeń. Obsługa w tych punktach powinna być zorganizowana $\mathrm{w}$ taki sposób, żeby wydanie lub wysłanie do pacjenta potrzebnych elementów mogło zostać przeprowadzone w tym samym lub następnym dniu roboczym. Baterie do procesora mowy powinny być dostępne dla użytkowników implantów w punktach serwisowych.
11.3 Poszczególne ośrodki powinny wdrażać politykę wymiany zgubionych lub uszkodzonych procesorów w sposób zapewniający równe traktowanie wszystkich dzieci.

11.4 Ośrodki wszczepiające implanty powinny mieć opracowaną strategię wymiany $\mathrm{w}$ razie potrzeby procesorów mowy na nowe modele.

\section{Awaria urządzenia}

12.1 W razie podejrzenia awarii części wewnętrznej systemu implantu należy wyznaczyć rodzicom/opiekunom bliski (nie dalszy niż na 3 dzień) termin konsultacji w celu skontrolowania działania elementów wewnętrznych i zewnętrznych.

12.2 W razie potrzeby należy bezzwłocznie skontaktować się z producentem systemu implantu ślimakowego odnośnie sprawdzenia urządzenia i zapewnienia odpowiedniego wsparcia technicznego, a w szczególności obecności przedstawiciela firmy podczas wizyty dziecka w ośrodku.

12.3 Po potwierdzeniu awarii części wewnętrznej systemu implantu ślimakowego personel kliniczny (patrz 2.1.c) musi poinformować chirurga i koordynatora/kierownika zespołu oraz wyznaczyć pacjentowi pilną konsultację w celu omówienia możliwości dalszego postępowania.

12.4 Awarię urządzenia należy zgłosić odpowiednim władzom krajowym.

12.5 Jeżeli została podjęta decyzja o reimplantacji, zabieg powinien zostać przeprowadzony najszybciej jak tylko jest to możliwe i stosowne ze względów medycznych, aby zminimalizować czas deprywacji słuchowej.

12.6 Reimplantacja i ustawienie procesora mowy powinny zostać przeprowadzone zgodnie $\mathrm{z}$ wyżej opisanymi zasadami. Należy też ocenić dalsze potrzeby (re)habilitacyjne pacjenta i w razie potrzeby zapewnić mu odpowiednią opiekę.

\section{Zarządzanie programem implantów ślimakowych}

Ośrodek wszczepiający implanty ślimakowe powinien prowadzić kontrolę wewnętrzną w następujących obszarach:

a. działalność kliniczna,

b. poziom zatrudnienia,

c. wyniki leczenia dzieci,

d. powikłania medyczne i chirurgiczne,

e. awarie urządzeń,

f. tematy działalności naukowo-badawczej i jej wyniki,

g. opinie dzieci i rodzin/opiekunów na temat świadczonych usług.

14 Współpraca zespołu implantów ślimakowych $z$ innymi zespołami $i$ instytucjami

14.1 Wszyscy członkowie zespołu implantów ślimakowych powinni brać udział w regularnych spotkaniach, umożliwiających dobrą komunikację w zespole i przez to wysoką jakość opieki zapewnianej każdemu pacjentowi. 
14.2 Członkowie zespołu implantów ślimakowych powinni podtrzymywać kontakt z lekarzem, który skierował pacjenta na diagnostykę w kierunku wszczepienia implantu ślimakowego, i z lokalnymi specjalistami zaangażowanymi w proces (re)habilitacji tego pacjenta.

14.3 Zespół implantów ślimakowych powinien rozważyć, jakie dodatkowe informacje mogą być użyteczne w procesie opieki nad pacjentem. Zespół ten powinien współpracować i uzyskiwać odpowiednie i aktualne informacje od innych instytucji, takich jak:
a. inne oddziały i kliniki szpitalne,
b. zespół audiologiczny, radiologiczny, fizyki medycznej, przychodnie i inne,
c. program badań przesiewowych noworodków,
d. grupy wsparcia,
e. instytucje samorządowe,
f. szkolnictwo.

14.4 Kontakt $\mathrm{z}$ instytucjami wspierającymi powinien być podejmowany wyłącznie za zgodą rodziców/opiekunów pacjenta, według uznania zespołu implantów ślimakowych.

\section{Przeniesienie opieki nad pacjentem (w kraju)}

15.1 Należy wdrożyć protokół przeniesienia opieki nad dziećmi - użytkownikami implantów ślimakowych po osiągnięciu przez nie odpowiedniego wieku do części programu zajmującej się dorosłymi.
15.2 Należy wdrożyć protokół przeniesienia na wniosek rodzica/opiekuna opieki nad dzieckiem do innego programu implantów ślimakowych oraz przejęcia opieki nad dzieckiem $\mathrm{z}$ innego programu.

15.3 Ośrodek, do którego przenoszona jest opieka nad pacjentem, musi potwierdzić, że może obsługiwać typ systemu implantu ślimakowego, z którego korzysta dziecko.

15.4 Dokumentacja pacjenta powinna za jego zgodą lub zgodą jego rodziców/opiekunów zostać przesłana do ośrodka, do którego przenoszona jest opieka. Dokumenty powinny zawierać: pełen adres pacjenta, numer telefonu i adres e-mail, informacje o tym, jakie urządzenie wewnętrzne posiada pacjent i z jakiego procesora mowy korzysta, jakie były ostatnie programy procesora, wyniki badania eCAP, eSRT, wyniki audiometrii wolnego pola $\mathrm{w}$ implancie, wyniki rozumienia mowy, raporty i wyniki (re)habilitacji, informacje medyczne o przebiegu operacji i ewentualnych powikłaniach.

15.5 Opieka nad pacjentem nie powinna być przenoszona do innego ośrodka wcześniej niż przed upływem roku od wszczepienia implantu. Czas ten jest potrzebny na kontynuację leczenia pooperacyjnego, ustawienie odpowiednich programów procesora i wstępną (re)habilitację pacjenta.

\section{Opinie i skargi}

Opinie dzieci i rodziców/opiekunów powinny być systematycznie zbierane w celu oceny i kontroli funkcjonowania programu implantów ślimakowych.

\section{Podziękowania:}

Zespoły eksperckie powołane w Instytucie Fizjologii i Patologii Słuchu w celu opracowania standardów w kwestiach:

- chirurgicznych

Henryk Skarżyński, Piotr H. Skarżyński

- diagnostycznych

Anna Fabijańska

- dopasowania implantów ślimakowych

Artur Lorens, Anita Obrycka, Adam Walkowiak, Małgorzata

Zgoda, Małgorzata Jeruzalska, Joanna Putkiewicz, Magdalena Maszewska
- dopasowania aparatów słuchowych

Anna Ratuszniak

- rehabilitacji

Anna Geremek-Samsonowicz, Agnieszka Pankowska

- badań obiektywnych

Krzysztof Kochanek, Wiesław Jędrzejczak

- badań obrazowych

Tomasz Wolak, Mariusz Furmanek 
